\title{
RISKS AND RETURNS \\ IN HEDGE FUNDS - ECONOMETRIC AND AUSTRIAN ECONOMIC PERSPECTIVES
}

\author{
MÓNICA VINJE REDPATH*
}

\begin{abstract}
Hedge funds and funds of hedge funds are some of the preferred ways to access capital market opportunities by institutional investors and high net worth individuals seeking vehicles of absolute return. Risks and returns are difficult to assess because of skewness and kurtosis so that traditional mean and variance analyses are inappropriate. I assess the possible implications of high leverage finance and financial innovations from an Austrian economic viewpoint on the basis of an econometric analysis of hedge fund risk adjusted returns and a historical consideration of asset price shocks in Thailand and Japan.
\end{abstract}

Key words: Hedge funds, leveraged finance, Austrian economics, monetary policy, risk.

JEL classification: B53, C01, E58, D53.

\section{I \\ INTRODUCTION}

Hedge funds (HF) and funds of hedge funds (FOF) are free-market entities that invest in alternative investment strategies with varying levels of risk, being actively managed in order to maximize returns for its investors given a specified target risk exposure. These investment vehicles are considered to be beta neutral, or not correlated to the financial market performance,

* Doctoral Program in Applied Economics. Faculty of Law and Social Sciences, University King Juan Carlos. Madrid. 
and they generate absolute returns (or alpha) based on the particular performance and skills of the fund's management. Hedge funds and FOF are becoming the preferred way to access alternative opportunities in capital markets, not only by institutional investors but also increasingly by high net worth individuals (HNWI) seeking high absolute returns with low correlation to the overall financial market performance. In the case of FOF, added advantages are their low initial investment, shorter lock-up time, low volatility, and double digit returns, as well as the advantages of the due diligence, transparency, and monitoring functions. However, the risks of high leverage finance assumed by FOF and HF have been historically underestimated in the world of alternative investments.

For their services, hedge fund managers charge a management fee and a performance fee, which is proportional to the returns above a hurdle rate. FOF charge an extra fee on top of the fees levied by the underlying constituent funds for management of the assets, as well as for the performance of each underlying fund. However, FOF managers have a challenging task. They assume the responsibility for investors of monitoring and reducing risk through portfolio rebalancing, as well as gaining exposure to sectors and assets with the best performance outlook. Managers of FOF perform top-down analysis, assessing where there is risk of low returns, where to take risk for higher returns, macro-trends or sector rotators. They also perform bottom-up analysis assessing the attractiveness of different sectors or the underlying fund manager's skills.

HF and FOF tackle opportunities with different strategies and with different instruments. Returns in hedge funds are notoriously asymmetrically distributed, presenting high kurtosis and negative skewness typically the result of trading in derivatives and illiquid securities in different markets. Managers in hedge funds have to continuously maintain a clear overview of the risk at the single security or asset class level and at the aggregated portfolio level in order to rebalance their portfolio, reducing undesired exposures and gaining exposure to risks providing superior returns.

In this paper, I review econometric analyses performed on hedge fund's risk and returns and consider these assessments under the conceptual framework offered by Austrian economics 
and the criticism to leveraged finance. While some hedge funds may use only their own funds and not leveraged finance for their investments, they use other sources of financial innovation to increase their credit capacity, while many others use leveraged finance typically up to 20 times their own capital, so clearly risk management is a critical aspect of hedge fund investment. I also consider some cases of asset price bubbles and systemic crises produced by the excessive use of leveraged finance and less than optimal bank capitalisation and deposit guarantees. This paper contributes to knowledge by critically assessing the econometric literature about risk and returns in high leveraged finance and by assessing these results from a political economic point of view using the framework of Austrian economics.

\section{II}

\section{HEDGE FUNDS AND RISK EXPOSURE}

\section{Risk and returns in different hedge fund strategies}

Institutional investors have traditionally used asset allocation as the core process to determine their investment strategy. This process is summarised as follows:

a. Selection of asset class

b. Improvement of initial constraints

c. Develop expected parameters

d. Define efficient frontier for risk and return patterns by allocation

e. Reassess asset allocation

f. Rebalance as required

g. Repeat process a-f

The process of asset allocation is important but it does not consider the dynamic changes in risk appetite and the changing dynamics of risk in the investment portfolio. Risk budget monitoring introduces a different dimension in the investment process as a function of volatility, correlation, and investment volume itself. 
If hedge funds are considered as an asset class by itself, then the allocation to underlying hedge funds in the FOF is an asset allocation problem. Asset allocation is concerned with optimal asset combination, so it is equivalent to a constrained optimization process in mathematical terms. Brinson et al. $(1986,1991)$ recognized that more than 90 percent of the variability of an investment portfolio is due to asset allocation. In order to diversify their portfolios, FOF managers invest in different strategies with trading in different asset classes. The advantage of the traditional asset allocation process is that the optimization process takes place at the asset class level instead of at the single security level and, in the FOF case, at the fund strategy level. It is then more straightforward to estimate consensus expected future returns at the hedge fund strategy level than at the single manager level and because the correlations are clearly established in order to build a diversified allocation. Empirical research (Lintner, 1983) has vigorously established the merits of including alternative assets in the allocation process given the low and often negative correlations with traditional asset classes. However, many FOF managers could shift their objective and allocate to underlying strategies with excessive risk and leverage for a given return in the attempt to justify their double fee structure.

$\mathrm{HF}$ and FOF allocation should not be seen as similar to a traditional portfolio optimization process using a mean-variance approach to efficiently allocate assets in a trade-off process of risk and returns. Optimal investment risk management has the aim to allow the investor to acquire less risk for a greater return or more return in exchange for the current risk exposure. Investment in hedge funds presenting significant asymmetries in their return distributions suggests that a mean-variance approach is not appropriate to achieve optimization. Agarwal and Naik (2001), based on the research by Fung and Hsieh (1998a and 1998b), established that a number of non-directional hedge fund trading strategies present return patterns similar to option based strategies. It can therefore be stated that option based trading strategies are an optimal proxy to assess hedge fund returns in some cases.

Hedge funds gain exposure to their own type of specific risks, such as through poor liquidity, use of leverage, frequent use of 
derivatives instruments, high turnover, and low correlation to traditional assets. Risk measurement in traditional investment vehicles or asset classes is relatively simple when compared with risk measurement in hedge funds. Two of the main challenges for investors assessing risk are the poor transparency of hedge funds, which is the main source of risk modelling misspecifications, and the non-stationarity of risk due to a hedge fund's dynamic investment strategies.

Under such circumstances, reducing measurement error to near zero becomes challenging. Identifying risk in a dynamic investment environment requires high frequency assessments, advanced information, and great accuracy and transparency. Factor analysis can be used to help identify important underlying risk factors and the rate of change of these factors, in either static, forward risk modelling, inverse risk modelling, dynamic factor analysis, and returns-based style analysis.

Static forward modelling (SFM) analyses the investment vehicle's returns and finds the factors that can fit in the return's model. SFM is a replication strategy using future contracts or other trading assets. In practice, SFM is used as an early warning system for the fund manager, because when a new factor emerges which can directly or indirectly negatively affect the portfolio returns, the manager has to locate the trader with possible exposure to that factor to reassess the portfolio exposure.

Forward risk modelling (FRM) assumes a set of pre-existing risk factors to assess the risk universe affecting the investment portfolio. If the investor has allocated investments to hedge funds using a convertible arbitrage strategy, it can be assumed that exposure to risk factors correlated to fixed income securities as well as stocks is obtained, because such an investment strategy is exposed not only to risk factors related to bonds but also because when the hedge fund manager exercises his option in a convertible bond, he is automatically gaining exposure to specific and market risks, as well as credit risk and volatility risk.

Inverse risk modelling (IRM) uses principal component analysis (PCA) to analyse the time series of returns and to establish all possible patterns with exposure to the risk factors explaining the returns. Using the covariance matrix, the eigenvectors are extracted 
with maximum explanatory power in statistical terms. These eigenvectors lack concrete correlation with actual economic factors, so the manager must correlate the characteristics of those statistical factors to real economic factors. In this case, interpretation is absolutely essential and in most cases extremely difficult and sometimes impossible. In this context, it is important to consider the common risk derived from the analysis by Fung and Hsie (2001), who developed a model based on asset-based style factors. Those factors with statistical significance may not necessarily be associated to any strategy or specific investment style. However, the clustering produced by the use PCA is able to group common risk and returns characteristics of a group of different hedge funds independent of their investment style or strategy.

Dynamic factor analysis considers relative changes of exposure along a time series of factors or combination of factors and their weights in explaining the returns of a portfolio. Managers have to evaluate a sufficiently long horizon that explains the tradeoff between risk and returns. In a time series, there is equilibrium between established risk factors and the returns when the factors and the returns converge. When the observation of returns and factors in the time series start to divert, the investor or FOF manager is left without knowledge of the risk factors. The use of multiscale correlation methods can assist establishing the right time horizon for the analysis. Two significant problems in the analysis are very frequent. The first is that the time horizon of the assessment is too short and the point of divergence (convergence) between the explaining factors and the portfolio return streams cannot be evaluated with a certain degree of accuracy. The second problem is that the established time horizon is too long, diluting the effects to such a degree that the factors combination and the moment relation cannot be visualized.

Detecting changes in correlations across time series is very useful because with assistance of this multi-scale correlation method, an error map can be built. If the error map becomes nonzero, it is because the correlation between the explaining factors and the returns has collapsed. Collapse in factors is a clear indicator that the fund manager has possibly changed the strategy 
or is entering into a strategy shifting process that should trigger an immediate explanation by the fund manager to the investor or FOF manager about this change and the new set of risk factors implied in such a strategic move and possible returns. Strategy shifting with consequent shifting in risk factors could offset the risk structure of the entire investment portfolio, accentuating or gaining a higher undesired level of overconcentration in certain exposures. Another indicator of strategy shifting is sudden factor dispersion, which is produced through introduction of new explanatory factors or alterations in the eigenvectors of the covariance matrix, which are statistical factors that have to be correlated to real factors.

Another system used by practitioners is the returns-based style analysis (RBSA) developed by Sharpe $(1988,1992)$. Although its application has been conceived for mutual funds analysis, it has been successfully used to assess style drifting by hedge fund managers and to identify when style reclassification is occurring. Given the rigidity of the investment mandate and their fiduciary responsibility, visualizing style drifting is of paramount importance for FOF managers with institutional investments in their portfolio. In order to better gauge underlying managers, the FOF manager preferably should have full position-level transparency.

\section{Risk measurement and management in HF and FOFs}

In HF and FOF management, investment portfolio risk budgeting aims to align risk budgeting with a coherent risk measurement methodology to then obtain an appropriate risk level. There are several value at risk (VaR) methodologies used, with conditioned value at risk $(\mathrm{CVaR})$ being the most commonly applied in the hedge fund industry (Rockefellar and Uryasev, 2000 and 2001), although $\mathrm{CVaR}$ is unable to describe all the risk dimensions, with the other most common method used being the mean absolute deviation model (MAD).

An essential component in hedge funds risk management is to also include the stress test in the risk measurement, assessment, and monitoring process. Stress analysis addresses various scenarios, 
such as which variables, given a certain rate of change, affect the price of an asset in the portfolio, to which degree and for which length of time; or in the case of a systemic crisis, how this will affect the portfolio valuation; or it can assess the impact of a change in a macroeconomic variable on the variation in a portfolio's returns. Stress analysis results need to be integrated into the denominator of the risk-adjusted reward equation and should include variations in market moves and assumptions of the underlying strategies, as well as the possible adverse effects on the portfolio of liquidity premiums and on-the-run and off-the run differential credit spread sensitivities. Scenario analysis is also used to model investment vehicle reactions to different market or economic environments (Ross, 2002). However, the attractivity of scenario analysis and its efficiency depends on the selection of the relevant variables.

In hedge fund management, another critical aspect is liquidity risk. Managers and investors need to understand that valuing positions at mid-market when positions are large and market liquidity is critical can be very misleading. A natural reflex when responding to pressures from prime brokers is in liquidating the most liquid instruments in the portfolio to meet margin demands during distressed situations. This is fatal to a fund because it constrains the portfolio to the most illiquid instruments leaving the managers in a very vulnerable position in a fast moving market. This was the one of the notorious main errors committed by LTCM (Long Term Capital Management) in 1998.

III

\section{VISUALIZING RISK EXPOSURES IN HF AND FOF}

\section{Detecting exposure concentrations in $\mathrm{HF}$ and FOF}

Different hedge fund strategies produce not only different returns but also different risk exposures and investors in HF or FOF managers should clearly visualize their exposures and the level of concentration to these risks at any given time. The investor should understand the normalized sum of squared styles concentration and FOF managers have to visualize their exposure to different sets 
of risks, which are implied in each hedge fund strategy, and also maintain a clear vision about the underlying common risk across different strategies in the constituent funds. Different data vendors providing style benchmarks have classified the major various hedge fund strategies, which are summarized in Table 1.

TABLE 1

DIFFERENT INVESTMENT STRATEGIES AS DESCRIBED BY THE MAIN HEDGE FUND INDEX PROVIDERS

\begin{tabular}{|c|c|}
\hline Credit Suisse Tremont & Hedge Fund Research \\
\hline $\begin{array}{l}\text { - Convertible Arbitrage } \\
\text { - Dedicated Short Bias } \\
\text { - Emerging Markets } \\
\text { - Event Driven (Distressed, Multi- } \\
\text { Strategy, Risk Arbitrage) } \\
\text { - Fixed Income Arbitrage } \\
\text { - Global Macro } \\
\text { - Long/Short Equity } \\
\text { - Managed Futures } \\
\text { - Market Neutral } \\
\text { - Multi-strategy }\end{array}$ & $\begin{array}{l}\text { - Convertible Arbitrage } \\
\text { - Distressed Securities } \\
\text { - Equity Hedge } \\
\text { - Equity Market Neutral } \\
\text { - Event Driven } \\
\text { - Macro } \\
\text { - Merger Arbitrage } \\
\text { - Relative Value Arbitrage }\end{array}$ \\
\hline Greenwich Alternative Investments & Barclay Hedge Fund Index \\
\hline $\begin{array}{l}\text { - Aggressive Growth } \\
\text { — Emerging Markets } \\
\text { — Equity Market Neutral } \\
\text { — Event Driven (Distressed Securities, } \\
\text { Merger Arbitrage, Special Situa- } \\
\text { tions) } \\
\text { - Futures } \\
\text { - Income } \\
\text { - Macro } \\
\text { - Market Neutral Arbitrage (Convert- } \\
\text { ible Arbitrage, Fixed Income Arbi- } \\
\text { trage, Statistical Arbitrage, Other } \\
\text { Arbitrage) } \\
\text { - Market Timing } \\
\text { - Multi-strategy } \\
\text { - Opportunistic } \\
\text { - Short Selling } \\
\text { - Value }\end{array}$ & $\begin{array}{l}\text { - Convertible Arbitrage } \\
\text { - Distressed Securities } \\
\text { - Emerging Markets } \\
\text { - Equity Long Bias } \\
\text { - Equity Long/Short } \\
\text { - Equity Market Neutral } \\
\text { - Equity Short Bias } \\
\text { - European Equities } \\
\text { - Event Driven } \\
\text { - Fixed Income Arbitrage } \\
\text { - Funds of Funds } \\
\text { - Global Macro } \\
\text { - Health Care \& Biotechnology } \\
\text { - Merger Arbitrage } \\
\text { - Multi-Strategy } \\
\text { - Pacific-Rim Equities } \\
\text { - Technology }\end{array}$ \\
\hline
\end{tabular}

Source: Author. 
Visualizing, qualifying, and quantifying risk exposure using statistical methods can assist investors or portfolio manager in evaluating the relevant risk factors related to the underlying constituent fund's strategy and to correlate them with real total risk factors of the FOF. This reduces the dimensionality of a multivariate forecasting overcoming the constraints imposed by the correlation of random variables and at the same time maintaining the covariation structure in the derived samples.

Assessing two funds using the same general strategy, it can be observed that the returns may be very unequal. In many cases, risks may be different or at least the risk factors would have different weightings in the matrix. For example, a hedge fund with the strategy equity long/short may be exposed to a certain industrial sector risk because it concentrates its portfolio in certain sectors which could have seasonal variations in its returns. Shortening also produces its own risks.

Short sellers speculate that the prices of the securities they are selling will collapse, selling loaned securities and waiting until the price collapses before replacing them in order to generate their margin. This strategy can also be used as hedging against a long position in a competitor or in fixed income securities from the same issuer. In the past, returns obtained by short selling securities went to finance the long only segment of the investment portfolio so that the entire portfolio would be leveraged to 100 percent or financed with zero capital or investment. Collateralization of short positions was the result of disastrous portfolio management practices where the long only segment lost money by decreasing securities prices and the short only segment was affected simultaneously by increases prices in the securities that were sold short, forcing the prime broker to increase margins in the traders account producing the liquidity squeeze effect. This risk is always present when short positions are negatively affected by market price developments, generating potential losses in the portfolio and forcing the prime broker to place margin calls to increase collateral in form of cash or securities to cover possible or effective losses, or when the prime broker calls the loaned securities, forcing the fund manager to generate losses from his short positions. 
Security markets demand that the seller of a security either has the security in his portfolio or can present assurances that the securities will be delivered by the time of the clearing of the trade. In hedge funds, this often occurs through loaning securities from specialized trading houses or from the prime broker, who demand as collateral the entire trade proceeds plus 20 to 30 percent in cash or other securities as an overcollateralization. Some trades are not cleared 2 weeks after execution because the short seller was unable to locate the securities he was short selling (naked selling) or he waited too long to purchase them in the capital markets to cheaper prices than sold, increasing their margin. In this case, the securities supervisory authority is entitled to start an inquiry about the objectives of such a trade and to impose penalties in form of fines or licence suspensions.

Ever since modern portfolio theory (MPT) was introduced by Markowitz (1952), the risk of a security has been measured by its variance, but this does not capture the entire dimension of risk and returns and particularly not for hedge funds. If two investors are holding the same portfolio of shares, but one of the investors bought an insurance in the form of an at-the-money put option, then the variance of both portfolios is the same but the risk is not the same because the probabilities of incurring a loss in the portfolio with insurance is limited to the premium of the derivative instrument, while the probabilities of a gain are open. In the other portfolio, the uninsured share has both downside and upside probabilities. If investors consider only the downside probabilities as measured by historical data presented in time series, then variance is not a comprehensive risk measurement. If a portfolio with both long and short positions carry two different risks that are not measured by the variance because of asymmetries in the returns and low market correlation, then only the long segment is subject to downside risk while the short only segment is subject to upside variance, because a rise in the shortened securities price will mean that the short only segment will suffer losses from the difference between the buying price and the liquidation price obtained by liquidating the position. Therefore, mean and variance is not always a sufficient risk measurement for a portfolio or even for a single security. 
In the optimal case, FOF or hedge fund portfolio managers have around 10 to 15 hedge funds in their investment portfolio under management (Lhabitant and Laporte, 2006); however, it is not uncommon to find FOF managers managing more than 50 and up to 110 managers through underlying constituent hedge funds in their different subportfolios, so it is easy to realize the level of complexity in different risk exposures.

\section{Leveraged finance - a very risky game}

Leveraged finance is at the source of a number of collapses and crises in recent times. In the case of the Asian crisis in 1997, many investors bought into a bubble market with borrowed money, buying real estate and security assets. In the case of Thailand, a bubble in real estate and the stock market resulted in a high demand for the Thai Baht, inducing pressure on the Bank of Thailand to appreciate the currency. Once the currency appreciated, Thailand lost its traditional export market (Japan) and investors started to sell Thai securities in the market. Hedge funds in particular started to short sell the Baht because they considered the currency peg unsustainable and this produced a selling stampede in capital markets. Pressure was induced on owners of real estate to liquidate their assets, producing at the same time a real estate asset price crisis. In the case of Japan, which avoided the twin crises (monetary and banking), the bubble in real estate cross-contaminated financial assets because up to 45 percent of the assets in Japanese corporations were represented by real estate assets. When the Bank of Japan (BOJ) increased the interest rates 3 times within a year, the entire system based on leveraged finance collapsed, exhibiting the low level of collaterization by most banks and financial institutions. Restrictions on lending (ceilings), as well as the Basel Accord, induced pressure on banks to maintain a minimum liquidity level of 4 percent for domestic institutions and 6 percent for international ones. In this respect, it is interesting to consider the conceptual framework and evidence presented by Bernanke and Gertler (1989) regarding the dynamic interaction between endogenous credit limits and asset prices, which constitutes an efficient transmission system allowing 
the effects of a shock to persist and spill over into the entire economy.

In general, research results have pointed in different directions regarding the underlying reasons for the Japanese crisis. Kashyap and Hoshi (2003) consider the most important reason to be the non-performing loans and the subsequent crisis of the banking business. Others, such as Prescott and Hayashi (2002), consider the main cause was primarily macroeconomic and fluctuations of Solow residuals and therefore assigned no significance to the investment frictions.

Since 1970, Caprio and Klingebiel (1999) have found evidence of 113 systemic banking crises that occurred in 93 different countries. In most of these cases, the principle causal factor was non-performing loans, predominantly real estate or real estate related loans. Some authors (Patrick, 1999) consider that important Japanese macroeconomic factors have enormously influenced the banking business from the 1970's onwards. Given the negative trend in the rate of economic growth, investment opportunities became scarcer and simultaneously, the retained earnings of corporations (Table 2) began to grow, making the corporate finance business from banks less relevant. However, it remains

TABLE 2

FUNDING OF PRINCIPAL INDUSTRIAL ENTERPRISE IN JAPAN FROM 1969 TO 1993

\begin{tabular}{|c|c|c|c|c|}
\hline \multicolumn{5}{|c|}{ Percentage of Total Supply of Funds } \\
\hline & & & \multicolumn{2}{|c|}{ DEBT } \\
\cline { 4 - 5 } Interval Years & Own Capital & Net Trade Credit & Borrowing & Bonds \\
\hline $1969-1973$ & 41.3 & 6.0 & 47.3 & 5.4 \\
$1974-1978$ & 53.3 & 5.1 & 31.8 & 9.8 \\
$1979-1983$ & 57.5 & 4.6 & 30.3 & 7.6 \\
$1984-1988$ & 76.6 & -0.1 & 8.7 & 16.1 \\
$1989-1993$ & 83.8 & 0.1 & 4.3 & 11.8 \\
\hline
\end{tabular}

Source: Based on Economic Statistics Annual, Bank of Japan. 
a fact that Japanese corporations were very active in raising funds in different capital markets, as Figure 1 illustrates.

In the case of Thailand, the Thai banking system did not have explicit blanket deposit insurance; however, the Bank of Thailand had an agency called the Financial Institution Development Fund (FIDF), which was built with contributions equivalent to 0.1 percent of the deposits of the banks or institutions being supervised by this agency. This agency lent money, purchased non-performing loans (NPL) from financial institutions in distress, or bailed them out at its discretion. In reality, this agency has operated as a guarantor of last resort, its credibility at a certain point becoming so important that banks never considered that a systemic crisis could be a possible scenario. This vision of the strategic bank management was described by Ungprakorn (1987, p. 25) as the absolute refusal of the Bank of Thailand to let fail any of the banks that were under its supervision.

\section{FIGURE 1}

TRENDS IN DOMESTIC AND FOREIGN BOND ISSUANCE BY JAPANESE CORPORATIONS

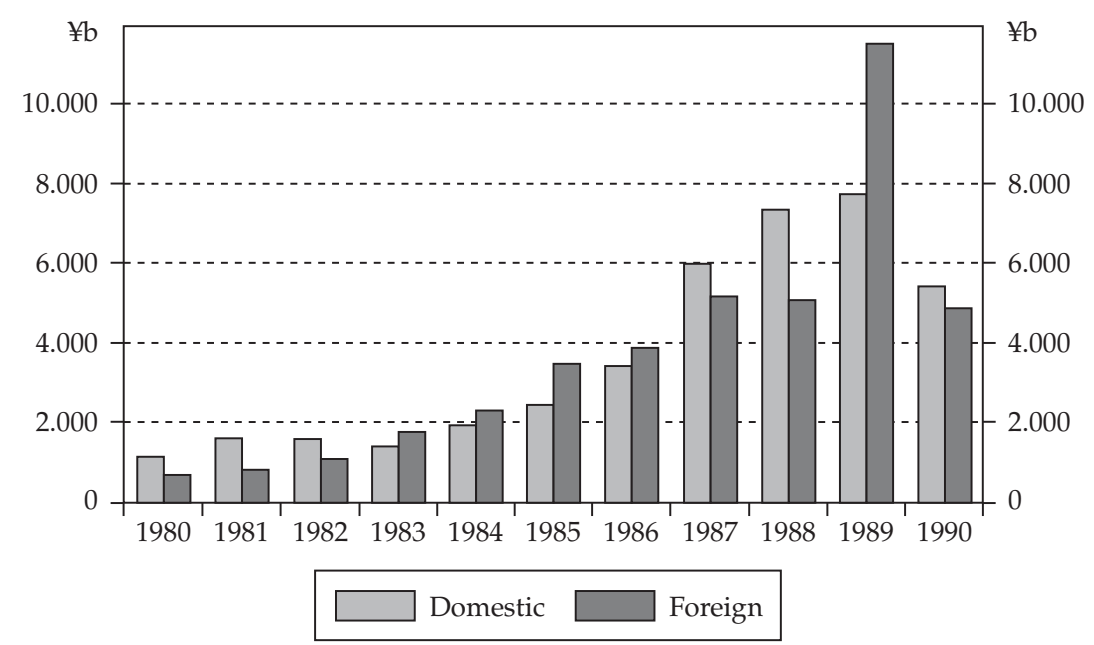

Source: Gower, L. (2000). 
The Bank of Thailand was firmly committed to support the Baht and its peg to the Dollar and raised the interest rates in 1995 because of economic developments, while simultaneously reinforcing regulations limiting the use of real estate as collateral for lending. The effect of such measures on the real estate market was devastating, eroding the valuations of the Baht denominated assets held by the financial institutions and investors. The Basel Accord was also in full effect and banks were under pressure to maintain their required capital requirement ratio, as explained earlier. The portfolio of NPL grew dramatically in the banking and financial communities, which had relied heavily on collateralizing loans with real estate assets, putting the financial system in distress.

In 1997, the FIDF bailed out 17 financial institutions, among them the most highly reputed ones, and let fail 42 others, which were suffocated by the weight of NPL in their portfolio and overexposure to real estate financing. By mid 1997, investors and particularly hedge funds realized that devaluating the Baht was necessary for Thailand to regain its competitiveness in international markets. They started to sell short Baht denominated assets and also the Baht in the capital markets, forcing the Bank of Thailand to sacrifice US\$ 20 billion in the defense of its currency.

In July 1997, the Bank of Thailand announced that the Baht would no longer hold to its currency peg system and that this would be replaced by a managed floating rate policy. Corporations and financial institutions, due to their large exposure to loans in foreign currency, became insolvent. Thailand, with its exhausted foreign reserves, was forced to recur to the IMF, which agreed to bail them out with an immediate credit of US $\$ 17.2$ billion, provided the government was firmly committed to undertake measures to restructure the financial sector (IMF, 1997).

Prior to the Japanese crisis, after the Ministry of Finance (MOF) imposed ceilings on the real estate lending activities of banks, the banks used regulatory arbitrage creating the Jusen, which were non-bank financial companies that were active in real estate finance. As result of higher cost of capital and regulatory liquidity coefficients imposed by the Basel Accord beginning in 1995, the Jusen and then loan cooperatives and other regional banks were declared insolvent and had to be liquidated as a result of the asset 
price deflation which left those financial companies with a large number of NPL. Shortly thereafter, Yamaichi and Sanyo, two of the most important securities companies, went out of business. Remarkably, some commercial banks meanwhile continued to increase their exposure to real estate assets, probably believing that the crisis was short lived and trying to seize perceived opportunities. In the meantime, the circle of collapse was closing in on the two most important and symbolic institutions of the postwar Japanese financial system, the Long Term Capital Bank and the Nippon Credit Bank ${ }^{1}$. The LTCB crisis would eventually became the largest bank failure in Japan's postwar history.

Due to the weight of their non-performing loans, several regional banks simultaneously entered into insolvency and the real dimension of the exposure of the Long Term Capital Bank and Nippon Credit Bank to NPL forced the MOF to intervene directly. The banks were unable to continue assisting each other in distress, as commonly agreed by the convoy policy, because the financial fragility had reached a systemic level that meant that the entire banking community could enter into insolvency and political opinion would not support using taxpayer funds to rescue them. Therefore, the BOJ abandoned their convoy policy and began to allow the banks to enter into bankruptcy ${ }^{2}$.

\section{IV}

\section{AUSTRIAN ECONOMICS - AN ANALYSIS FRAMEWORK FOR LEVERAGED FINANCE}

\section{Hedge Funds and Systemic Crises}

As we can see, a number of researchers have established that regulatory limitations on lending were at the source of the crises in the Far East. However, the fact that regulations demanded a

\footnotetext{
${ }^{1}$ Long Term Capital Bank and Nippon Credit Bank were the largest banks in Japan, created after the war with the scope to actively contribute to Japan's reconstruction.

2 The cost of the Jusen crisis climbed to 6,410 billion yen, which was financed by the Jusen founding institutions up to 55 percent, 27 percent by other lending institutions, 8 percent by rural banks, and only 10 percent by public funds (Miyajima and Yafeh, 2003).
} 
minimal liquidity or collateralization by financial institutions in the order of 4 to 8 percent should not be the main reason for declaring the entire financial system effectively bankrupt, as happened in both Thailand and Japan. Austrian economics considers that in order to avoid this kind of cyclical financial crisis, a system of 100 percent reserve would be able to pre-empt these kinds of systemic shocks (Huerta de Soto, 2006, pp. 745746). Hedge funds had an important role not only during the Asian crisis, where according to several accounts they managed to achieve profits in the order of USD 500 billion, but also in the Russian crisis where hedge funds lost enormous amounts. The low level of collateralization by financial institutions including central banks has served as catalyzator of the crises allowing hedge funds (Far East) to make profits where they were short and make losses (Russia) where they were long. In the case of Russia, investor losses were triggered by the decision of the Russian government to default on its sovereign debt, because they were not observant of the principles of the 100 percent reserve.

Until now, the importance of leverage in analysing the returns of investment vehicles has been understated, and the returns analysis has been mainly based on quadratic investor preferences that consider only 2 moments, the mean and variance, without taking into account the third and fourth moments. In this case, the capital asset price model (CAPM) does not consider the effects of skewness and kurtosis, which affect negatively (or positively) investor's preferences. The concept in Austrian economics about deposit guarantees is in line with investors' risk averseness, considering further moments in investors' preference beyond the two moments theory, as expressed in research by Pratt (1964) and Arrow (1965) on the risk tolerance of economic agents, where a utility function was developed that can be used for the measurement of the level of risk tolerance. Consider the measurement of absolute risk aversion as:

$$
A(W)=-\frac{U^{\prime \prime}(W)}{U^{\prime}(W)}
$$


and the decreasing absolute risk aversion should be considered as:

$$
A^{\prime}(W)<0
$$

The absolute risk aversion function measures the level of risk aversion given a level of wealth of the economic agent. Moreover, the relative risk aversion of an economic agent can be measured with the following function:

$$
R(W)=-\frac{W U^{\prime \prime}(W)}{U^{\prime}(W)}
$$

and the decreasing relative risk aversion should be considered as:

$$
R^{\prime}(W)<0
$$

Where $W$ designates the wealth of the economic agent or, in this case, the investor. However, such equations are limited in their applicability and are especially good at expressing a neoclassical equilibrium state, whereas from the Austrian viewpoint, they cannot include non-mathematical phenomena, such as the subjective reality of time or the entrepreneurial creativity (Huerta de Soto, 1998).

Under this framework, the averseness to risk given by the effect of negative skewness and high kurtosis is not considered, nor is the high probability of incurring large losses or the low probability of making large gains. The persistence of returns of hedge funds in a financial high leveraged environment contrary to what Austrian economics recommends could not necessarily be the result of manager's skill, as exhibited by the alpha coefficient but rather the product of serial correlations of any sign. This would be in line with the Efficient Market Hypothesis (EMH), since as LeRoy (1973), Rubinstein (1976) and Lucas (1978) and others demonstrated, serial correlations in assets returns are not to be considered as a result of market inefficiencies but rather as time 
varying expected returns. Nevertheless, one can question the validity of such an argument in relation to hedge fund returns because this theoretic main framework ignores market frictions, liquidity constraints, and transaction costs. Kadlec and Patterson (1999) in their research established the impossibility to detect serial correlations larger than the order of 10 to 15 percent in US investment portfolios due to nonsynchronous trading effects; nevertheless, it is conceivable that in the case of hedge funds trading in illiquid securities, short selling and the wide use of derivative instruments could explain the serial correlations in the returns. Moreover, Lo and MacKinlay (1990), established that in order to induce serial correlations in U.S. investment portfolios in the order of 30 percent or more, the portfolio would have to go without trading for an interval of several days.

The fact that the entire capital market works on the basis of leverage with the complacency of the monetary authorities is remarkable, particularly since according to a recent article published in the Wall Street Journal, the collateral behind all the world transactions is not more than 8 percent. This latter benchmark has to be understood as a significant advance in world financial architecture, because in 1998 the liquid collateral was not more than 4 percent. Therefore, considering that the entire world financial architecture relies exclusively on the use of leverage, one can question how that could be different in the case of central banking. Different capital adequacy measures taken by regulatory authorities tend to maintain a minimum adequacy that is considered today to be between 4 to 8 percent. The Austrian economic position about capital adequacy is based on the concept of a 100 percent deposit guarantee, which by all means is not the intention of anyone in the financial world because that would eliminate the profits of so many making money without having to actually invest it, by pretending to invest in the form of collateral guarantees that are not actually guaranteed. In this frame, one must consider the criticisms to financial innovation, such as those made by Huerta de Soto (2006, pp. 769773), where these innovations are nothing less than allowing one to make money without actually risking any and yet cashing risk premiums. 


\section{Austrian economics and the probability of systemic crisis}

It has been formulated that the probability of systemic crises under a system of 100 percent deposit guarantee is unlikely (Huerta de Soto, 2006). The creation of booms and busts through credit expansion by monetary authorities allows hedge funds to take advantage of these particular economic distortions. As established before, many systemic crises were the result of high leverage finance. The collateralization demanded by Austrian economics would eliminate the crises that are originated through leveraged finance by inducing a stability frame. Given the fact that the cyclicalities of the crises are caused by the monetary authorities trying to control overheated economic growth by way of contracting monetary instruments or by way of interest rates, we have to conclude that the cyclical effect will be eroded because the collateralization effect will be such that there would be an elimination of the probability of overheating. All that is expended is what there is to expend, so there would not be an overexposure to bubbles because of cheap leverage and therefore, there would not be crises because there would not be the formation of asset bubbles.

\section{The problem of the fees from an Austrian economic perspective: Fees for what?}

As expressed before, one of the most problematic situations is the process of wealth transfer between the investor and the HF or FOF manager. This is particularly apparent in the case of FOF, because it is one of the few investment vehicles where managers can receive a performance fee also when the fund is losing money. The performance fee can be considered as a reward to managers for obtaining a certain performance above a risk free rate of return, which would be represented by a 1 year bond. The process of wealth creation means that the manager that outperforms a passive investment instrument, such as a 1 year bond, will be compensated with a performance fee in the form of a proportion of the performance above a hurdle rate 
(T Bond). This compensation mechanism means that there is wealth creation by way of the manager identifying market inefficiencies and betting on convergences (divergences) would create wealth by inducing investment in securities that have been undervalued and withdrawing investment from securities that are overpriced (short selling) in a typical arbitrage transaction.

An inverse wealth creation process can take place in the case of FOF. In the FOF, the manager gets a performance fee on top of the performance fee charged by each of the underlying performing constituent funds. However, if one or more of the underlying funds loses money in a way that the performance of the overall fund is negative, the investor does not have to pay any performance fee on the money losing underlying fund but, since he is paying on the performing funds a double layer of fees, it is possible that the entire investment in the fund is underperforming and yet the investor is paying a performance fee. This is a process where wealth is destroyed and investors pay a fee for its destruction. It is a typical case where it can be stated that hedge funds do not create wealth.

In general terms, performance is paid only for the performance above a hurdle rate and if the fund is not performing, it does not receive any fee. There is also another factor that incentivates hedge fund managers to create wealth for their clients, which is the watermark. A watermark agreement is a normal part of a hedge fund management mandate and it means that if a single manager fund loses money over a certain time period, he will not charge a performance fee until he recovers the amount lost. So, if the investment was 100 and in first period, the fund underperformed by 10 percent, the investor does not pay a performance fee. In the next period, the fund that was at 90 reaches 100 , and this means there is more than $10 \%$ performance, but the manager still does not charge a performance fee. If the fund would have made 120, the manager would have charged a performance fee on the 20 and not on the 30, because 10 were to compensate investors for the losses in the previous period. 


\section{Financial innovations and Austrian economics}

Hedge funds are entrepreneurial ventures operating at the frontiers of finance. Certain strategies are oriented to take advantage of securities mispricing and others of different market inefficiencies. The theory of a 100 percent deposit guarantee becomes a discussion topic when different central banks apply different interest rates in order to stop inflation or to incentivate spending. But different central bank policies also offer different arbitrage opportunities. For instance, when the Bank of Japan (BOJ) offers money to 0.5 percent per annum plus risk premium, while at the same time Icelandic bonds pay $16.5 \%$, investors can make an arbitrage called carry trade by putting some collateral, borrowing yen and investing in Icelandic sovereign bonds. The use of derivatives can be implemented in order to hedge currency and interest rate risks. In this way, a fund implementing this fixed income arbitrage strategy can return to investors significant profits with a very low volatility as measured by the volatility of the currencies and the volatility of the interest rate.

Shortening has the effect of increasing credit expansion, because normally the shares are borrowed by the HF and then sold at a certain price, only to be replaced and returned to the owner at a later date at a lower cost as the share price falls. The shortening proceeds can then be invested into other assets to produce returns, typically into equities that are considered undervalued. Despite their generally favourable view by Austrian economists (Huerta de Soto, 2006, pp. 584-596), life insurance companies are a major owner of the loaned shares used for shortening purposes, earning income from the share rental. Despite their fiduciary mandate that specifically bars them from shortening shares, life and other insurance companies are important investors in HF and FOF who do short stocks as part of their investment strategy, which produces a regulatory arbitrage. In their investment strategy, insurance companies apply asset liability management (ALM), in order to match the duration of the investment with their expected disbursements.

Not all capital guarantee products are the same. Capital guarantee products are produced by financial engineering, taking advantage of discounts as well mispricing of highly rated zero coupon bonds, 
which are used to guarantee the principal at maturity in line with the investment horizon. The remaining investment is allocated to a portfolio of securities providing more risk for higher returns, so that if a loss of the speculative capital happens, in the worst case scenario the investor will recover his invested capital at the end of the investment horizon, which will proceed from liquidating the high rated zero coupon fixed income security (bond). These capital guaranteed products are redeemable only at maturity and not at any time. However, other financial products, such as some REITs (real estate investment trusts), mutual funds, and hedge funds, and in general investment vehicles in illiquid securities giving the investors the right to redeem their shares with a short notice period, which is not in relation to the duration of the investment, give rise to the problem described by Huerta de Soto (2006, p. 598), where they run the risk of not being able to immediately comply with the exercise of the repurchase option or redemption. In 2006, Deutsche Bank's REIT had to suspend their payment of redemptions because of the illiquid character of their investments did not match the duration of the investments. Life insurance companies are not exempt from this problem because they invest in investment vehicles that allocate to illiquid securities.

Within this context, it is interesting to remark that research by Martellini and Ziemann (2005) has established a model how investments in alternative asset classes, particularly in hedge funds, can be implemented by institutional investors, such as life insurance companies, under the constraints of ALM (asset liability management) in order to minimize extreme risks as measured by $\mathrm{VaR}$ of the overall portfolio. Nevertheless, we have to consider that VaR is a symmetrical risk measurement lacking coherency because asset returns are often everything but normally distributed, and VaR violates the second order stochastic dominance and therefore is not in line with traditional investor's risk aversion (Gutthof et al., 1998). Moreover, optimization of the investment portfolio enters into conflict with VaR because it is not sub-additive. A fund manager led by the VaR and seeking to minimize risk may be tempted to divide a two fund portfolio into two single fund sub-portfolios, creating an inefficient investment allocation with negative impact to manager reward schemes (Artzner et al., 1997, 1999). 


\section{Are hedge funds entrepreneurs that create wealth?}

Fund managers are entrepreneurial in nature, focused on generating absolute returns for their investors through various strategies that take advantage of market inefficiencies, mispricing, timing, and other inefficiencies, generating profits at the frontiers of finance. Rothbard (1993) defines an entrepreneur as an individual who is prepared to confront uncertainties already inherent in the market, and who has the skills to do this. Mises (1998) states that «the entrepreneurial idea that carries on and brings profit is precisely that idea which did not occur to the majority. It is not correct foresight as such that yields profits, but foresight better than that of the rest. The prize goes only to the dissenters, who do not let themselves be misled by the errors accepted by the multitude What makes profits emerge is the provision for future needs for which others have neglected to make adequate provision.» While some HF may put a strong focus on quantitative analysis to determine investment strategies, others recognise that information is subjective and that markets "give rise to the formation of potential opportunities of entrepreneurial gain, which tend to be discovered and made use of by the entrepreneurs in the coordination process that they are continually stimulating in the market» (Huerta de Soto, 1998).

Some of the most common hedge fund investment strategies include the use of long and short equity investments, where securities considered undervalued are bought long in the expectation that they will appreciate, and conversely sold short when securities are considered overvalued; convertible bond arbitrage, where convertible bonds are purchased and price changes in the underlying equities generate profits and risks are hedged; relative value securities arbitrage, using various analyses to identify securities mispricing; merger arbitrage, buying and selling of companies involved in mergers; distressed securities, buying distressed or restructuring companies; event driven or activist, taking advantage of various factors that can affect equity prices; and speculative trading on global macro trends.

Depending on the investment strategy taken, hedge funds can create wealth in various ways by taking money from investors and bringing it to opportunities that are not normally considered 
by the ordinary investor. An individual investor with USD 500,000 to invest but without a team of analysts would not be able to access the opportunities that are identified by HF and, without the HF, the efficiency of the individual investment could be very limited because it would be fragmented over different securities and time. HF investing quantitatively higher volumes are able to offer publicly listed companies more efficient capital to the very companies that need the money to better perform. An activist hedge fund identifies companies with poor management or other weaknesses, and through corporate political power obtained through share ownership force changes in the company beyond corporate governance to increase shareholder value. Similarly, HF investing in distressed securities take troubled companies and restructure them to maximize the value that can be obtained, helping to avoid the company's entry into bankruptcy or closure. Private equity hedge funds take state companies which are being privatized and restructure and sell them either to capital markets or to other companies. By injecting investment into small and medium cap companies listed in capital markets, these investment targets are allowed to better expand and compete due to the availability of capital and therefore produce better performance and bringing considerable results to shareholders.

Other types of investment strategies, such as statistical arbitrage, short/long, or equity neutral create wealth only for the HF and its investors, through the use of arbitrage to extract value from mispricing situations.

\section{$\mathrm{V}$ \\ CONCLUSIONS}

Hedge funds and FOF are becoming the preferred way to access alternative opportunities in capital markets. However, the risks of high leverage finance assumed by FOF and HF have been historically underestimated in the world of alternative investments. Returns in hedge funds are notoriously asymmetrically distributed, presenting high kurtosis and negative skewness typically the result of trading in derivatives and illiquid securities in different 
markets. Managers in hedge funds have to continuously maintain a clear overview of the risk at the single security or asset class level and at the aggregated portfolio level in order to rebalance their portfolio, reducing undesired exposures and gaining exposure to risks providing superior returns.

In this paper, I reviewed econometric analyses performed on hedge fund's risk and returns and considered these assessments under the conceptual framework offered by Austrian economics and the criticism to leveraged finance. Hedge funds gain exposure to their own type of specific risks, such as through poor liquidity, use of leverage, frequent use of derivatives instruments, high turnover, and low correlation to traditional assets. Identifying risk in a dynamic investment environment requires high frequency assessments, advanced information, and great accuracy and transparency. Various types of factor analysis can be used to help identify important underlying risk factors and the rate of change of these factors.

I also considered some cases of asset price bubbles and systemic crises produced by the excessive use of leveraged finance and less than optimal bank capitalisation and deposit guarantees. Leveraged finance is at the source of a number of collapses and crises in recent times, including the crises in Japan and Thailand during the 1990s. The low level of collateralization by financial institutions including central banks has served as a catalyzator of the crises allowing hedge funds (Far East) to make profits where they were short and make losses (Russia) where they were long. The collateralization demanded by Austrian economics would eliminate the crises that originate through leveraged finance by inducing a stability frame. The fact that the entire capital market works on the basis of leverage with the complacency of the monetary authorities is remarkable.

Shortening and other financial innovations used by HF can have the effect to increase credit expansion. Regulatory arbitrage is routinely used by life and other insurance companies to bypass their fiduciary mandates that specifically bar them from activities such as shortening, and these organisations have become important investors in HF and FOF who do short stocks as part of their investment strategy. Life insurance companies may invest 
in investment vehicles that allocate to illiquid securities, so that some capital guarantee products are not able to immediately comply with the exercise of the repurchase option or redemption at any time. In their investment strategy, insurance companies should apply asset liability management in order to match the duration of the investment with their expected disbursements.

\section{BIBLIOGRAPHICAL REFERENCES}

AgarWal, V. and NAIK, N.Y. (2001): «Performance evaluation of hedge funds with option-based and buy-and-hold strategies», Working Paper, London Business School.

Arrow, K.J. (1965): Aspects of the Theory of Risk-Bearing. Helsinki: Yrjö Hahnsson Foundation.

Artzner, P., Delbaen, F., Eber, J.-M. and Heath, D. (1997): «Thinking Coherently», Risk Books, pp. 68-71.

- (1999): «Coherent Measures of Risk», Mathematical Finance, 3 (9), 203-28.

BernanKe, B. and GertLer, M. (1989): «Agency Costs, Net Worth, and Business Fluctuations», American Economic Review, 79, 14-31.

BRINSON G.P., HOOD, L.R. and BEEBOWER, G.L. (1986): «Determinants of portfolio performance II: an update», Financial Analysts Journal, July-August.

BRINSON G.P., SiNGER, B.D. and BEEBOWER, G.L. (1991): «Determinants of portfolio performance II: an update», Financial Analysts Journal, May-June.

CAPRIO G. JR. and Klingebiel, D. (1999): Episodes of Systemic and Borderline Financial Crises, World Bank, mimeo.

Kadlec, G. and Patterson, D. (1999): «A Transaction Data Analysis of Nonsynchronous Trading», Review of Financial Studies, vol. 12, pp. 609-30.

KASHYAP, A. and HoshI, T. (2003): «Japan's Economic and Financial Crisis: An Overview», Journal of Economic Prospective, Forthcoming Winter 2004.

Fung, W. and HsieH, D.A. (1998a): «Price trend following trading strategies: theory and empirical evidence», Working Paper, Foundation of Managed Derivatives Research, September. 
- (1998b): «A risk neutral approach to valuing trend following trading strategies», Working Paper, Duke University.

- (2001): «The risk in hedge fund strategies: theory and evidence of trend follower», Review of Financial Studies, vol. 41, pp. 31341.

Gower, L. (2000): «Some Structural Causes of Japan's Banking Problems,» Economic Research Department, Reserve Bank of Australia.

Guthoff, A., Pfingsten, A. and Wolf, J. (1998): «Der Einfluss einer Begrenzungdes Value at Risk oder des Lower Partial Moment Oneauf die Risikoübernahme», in A. Oehler, ed. Credit Risk und Value-at-Risk Alternativen, Schaffer-Poeschel Verlag, Stuttgart, pp. 111-53.

Huerta DE SOTO, J. (1998): «The Ongoing Methodenstreit of the Austrian School», available at http:/ / www.jesushuertadesoto.com. Reedited in (2008) The Theory of Dinamic Efficiency, London an New York (Routledge).

- (2006): Money, Bank Credit, and Economic Cycles, Auburn, Ala., Ludwig von Mises Institute (2nd edition 2009).

International Monetary Fund (1997): World Economic Outlook, Interim Assessment, December, p. 51.

LeRoy, S. (1973): «Risk Aversion and the Martingale Property of Stock Returns», International Economic Review, 14, pp. 43646.

Lhabitant, Francois-Serge and Laporte, N. (2006): «Funds of funds of hedge funds: welcome to diworsification», in G. Gregoriou, Ed. Funds of Hedge Funds, Performance, Assessment, Diversification, and Statistical Properties, Elsevier Finance.

LiNTNER, J. (1983): «The potential role of managed commodityfinancial futures accounts (and/or funds) in portfolios of stocks and bonds». Presentation at the Financial Analysts Federation.

Lo, A. and MacKinlay, C. (1990): "A Non-Random Walk Down Wall Street», Princeton, N.J., Princeton University Press.

Lucas, R. (1978): «Assets Prices in an Exchange Economy», Econometrica, 46, pp. 1429-46.

Markowitz, H. (1952): «Portfolio Selection», Journal of Finance, vol. 7, pp. 77-91 
Martellini, L. and ZiemanN, V. (2005): «The Benefits of Hedge Funds in Asset Liability Management», working paper, EDHEC Risk and Asset Management Research Centre, Sept. 2005 Mises, L. VON, (1998): «Human Action: A Treatise on Economics,» Auburn, Ala., Ludwig von Mises Institute.

Myajima, H. and YafeH, Y. (2003): «Japan's Banking Crisis: Who has the Most to Lose?», RIETI Discussion Paper Series 03E-010.

Patrik, H. (1999): «The Causes of Japan's Financial Crisis», Pacific Economic Papers, 288, The Australia-Japan Research Centre, The Australian National University.

Pratt, J.W. (1964): «Risk Aversion in the Small and in the Large», Econometrica, Vol. 32, pp. 122-36

Prescott, E. and Hayashi, F. (2002): «The 1990's in Japan: A Lost Decade» Review of Economic Dynamics 5, 1.

ROCKEFELLAR, R.T. and URYASEV, S. (2000): «Optimization of Conditional Value-at-Risk», Journal of Risk, vol. 2, pp. 21-41

- (2001): «Conditional Value-at-Risk for General Loss Distributions», Research Report 2001-5. ISE Dept. University of Florida.

Ross, L. (2002): «Risk Exposure and Hedge Funds», Russell Research Commentary, Tacoma, WA.

Rothbard, M.N. (1993): «Man, Economy, and State: A Treatise on Economic Principles», $3^{\text {rd }}$. ed., Auburn, Ala., Ludwig von Mises Institute.

RUBINSTEIN, M. (1976): «The Valuations of Uncertain Income Streams and the Pricing of Options», Bell Journal of Economics, 7, pp. $407-25$.

Sharpe, W. (1988): «Determining a Fund's Effective Asset Mix», Investment Management Review, December, pp. 59-69.

- (1992): «Asset Management: Management Style and Performance Measurement», Journal of Portfolio Management, 18 (2), pp. 7-19.

UngPRAKORN, P. (1987): «Regulators Under Fire over Siam City Affair» Financial Times, January 1987 p. 25 cited in Herring $\mathcal{E}$ Wachter (1999). 